\title{
Ecotoxicology and Testicular Damage (Environmental Chemical Pollution). A Review
}

\author{
Ecotoxicología y Daño Testicular. (Contaminación Química Ambiental). Revisión \\ Eduardo Bustos-Obregón \& Ricardo Hartley B.
}

\begin{abstract}
BUSTOS-OBREGÓN, E. \& HARTLEY, B. R. Ecotoxicology and testicular damage (Environmental chemical pollution). A Review. Int. J. Morphol., 26(4):833-840, 2008.

SUMMARY: This review briefly considers the testicular damage elicited by environmental chemical pollution. It includes a short comment on environmental toxicology as an introduction to environmental chemical pollution, highlighting the importance of this current field of study and its impact on male reproductive health. Furthermore an experimental animal model addressing the effect of organophosphorated agropesticides as a testicular toxicant is presented. Moreover two relevant chemical contaminants and their effect on the testis, such as the classical case of lead and the rarely reported case of Boron on spermatogenesis, are considered. Additionally, the subject of biosentinel species and their relevance for the monitoring of pollution in aquatic and/or terrestrial ecosystems is considered. In conclusion, it should be stressed that environmental health is closely related to the reproductive health of all living beings.
\end{abstract}

KEY WORDS: Environmental chemical pollution-testicular damage.

\section{GENERAL CONCEPTS ON ENVIROMENTAL TOXICOLOGY}

Environmental toxicology studies the effect of environmental toxicants on the health of all organisms and on the different compartments of the environment. Its concern involves the fact that human survival depends on the preservation of other animal and plant species and on the environmental resources such as clean air, food and water, which are menaced mostly by anthropogenic chemicals that alter living organisms and ecological processes.

Therefore, ecotoxicology deals with two orientations: regulation and research (Ming-Ho Yu, 2005).

Chemical pollution and testicular function has been the subject of great concern in the last decades; so much so, that in 1970, a classical four volume book, "The Testis" was published. Volume III has two chapters (chapter 10 and 11) devoted respectively to the effect of cadmium on the testis and other mineral elements and chemical agents affecting testicular function and male fertility. Both chapters deserve a careful review by anyone interested in this area (Johnson et al., 1970).

An interesting comparison between Environmental Toxicology, which is our main subject in this chapter, and
Ecotoxicology (that refers more to the impact of xenobiotics upon the environment) is found in the book "As bases toxicológicas da Ecotoxicología" (De Azevedo \& Da Matta Chasin, 2003).

A short review on specific chemical pollution such as agropesticides was recently published by our group. (BustosObregón, 2001).

In recent years, there has been growing concern on the deleterious effects that many chemicals may have on male reproduction. These substances may act as testicular toxicants and correspond to different compounds, which are related to social habits, life conditions, working hazards or use of drugs and medicines (Bustos-Obregón, 2001; Johnson et al.; Pomerol \& Arrondo, 1994).

The increase of environmental chemical pollution becomes evermore apparent when one considers that today there are 4 million organic environmental contaminants, and this number increases in $100 \%$ yearly. Globally, there are 100.000 products annually manufactured in the order of 200 million tons. per year. They contaminate $30 \%$ of the waters and $70 \%$ of the general environment. Moreover, many research 
groups in the world are starting to analyze so called "emerging pollutants" (Bustos-Obregón, 2001; Bustos-Obregón, 2007).

\section{ENVIRONMENTAL CHEMICAL POLLUTION}

Our interest is on the male reproductive factor since most of these substances are testicular toxicants, present as occupational risk (i.e. agropesticides) or indiscriminate use of drugs without appropriate prescription or medical surveillance.

Due to the large numbers of chemical contaminants, very few of them have been analyzed regarding their developmental or reproductive toxicity, considering the economical costs involved. Thus, the percentage of analysis is $34 \%$ of Pesticides, $22 \%$ of Cosmetics, $45 \%$ of Medicines and $20 \%$ of Food additives.

Even if many organophosphorates have been banned internationally because of their high toxicity for human and animal health, many are still illegally used.

The effect of different toxicants is registered at different levels of the male reproductive tract, thus rendering the analysis of reproductive damage much more complicated.

\section{HUMAN REPRODUCTIVE MALE HEALTH}

Occupational and enviromental influences on male fertility are at present of concern. Andrological text books devote chapters to this issue, such as Brinkworth \& Handelsman (1997), in "Andrology Male Reproductive Health and Disfunction" (Nieschlag \& Belise eds, 1997).

It may be observed that many hazardous factors exist and different foci of attention are considered initially: acute toxicity, carcinogenesis and teratogenesis are the key points. Reproductive and genetic toxicity have emerged at present as rapidly developing areas of clinical and basic (animal) research. It should be kept in mind that the contrast between data from experimental studies and observational data in human exemplifies an important distinction in toxicology, that between hazard and risk. Experiments aimed purely at determining whether an agent has the potential to damage a biological system are concerned with hazard. The concept of risk combines hazard and the biological context. It incorporates not only the level of exposure but levels reaching the target tissue, the effects of toxifying/detoxifying metabolic systems, repair processes, and any other factors modulating the final response. The ultimate objective of toxicological investigations is thus not only to identify particular compounds as hazardous, but to provide the best possible assessment of the risks they pose to humans.

Adverse effects on spermatogenesis may be identified as pre, testicular or post-testicular cases according to the target of toxicity (Brinkworth \& Handelsman). Testicular cases are the more frequent and usually worse situations depending on the time and frequency of exposure and the testicular toxicant involved. On reviewing risk for agroworkers exposed to organophosphorated (OP) pesticides, our group stressed the social and economical problems faced in Latin-America today in spite of legal protective regulations that are seldomly observed (Bustos-Obregón, 2001).

A retrospective study was conducted on the agroworkers in the banana plantations of Chinandega, Nicaragua, that used dibromochloropropane (DBCP) in their work during the decade of 1970 `s, to analyze their present (2005) seminal status by performing seminogram analysis, according to the WHO Laboratory Manual. In the more severe cases, testicular biopsies were obtained and general absence of spermatogenic activity was found with a histological aspect like the Sertoli-only syndrome. The study considered 400 workers with different degrees of exposure, and in general, all sperm parameters were decreased significantly in terms of sperm count, motility, vitality and morphological normality, thus stressing the importance of adequate control of the exposed agroworkers (Ortiz, 2006).

\section{ANIMAL MODELS. ORGANOPHOSPHORATED (OP) AGROPESTICIDES}

Agropesticides are of ample world-wide use. Among them, organophosphoric (OP) compounds, though restricted in many countries, are nevertheless employed in numerous places.

In 1950 the OP Malathion (S-(1,2-bis-(etoxi-carbonyl)ethyl)-0,0-dimethyl-dithiophosphate) was introduced as being less toxic than Parathion. Both act by inhibiting acetylcholinesterase activity (Hsu et al., 1989). Residues of these OP are environmental contaminants nowadays, (Gomero \& Von Hildebrand, 1990), thus altering the biotic (animals, plants) and abiotic (earth, atmosphere, waters) systems and representing a public health problem in many agricultural communities (Ortiz-Hernández et al., 1997). The OP compounds are lipophilic, (Ferrer \& Martínez, 1993), and they concentrate in adipose tissue from which they may be released as active metabolites (the "oxon" derivative) and elicit the so-called endogenous re-intoxication (Martínez, 1992). 
Biotransformation of OP, mostly by hepatic enzymes, renders them more hydrosoluble to allow excretion of these chemicals (Chapalamadugu \& Chaudhry, 1992).

In addition to the inhibition of cholinesterase activity (resulting in accumulation of acetylcholine in the synapses and excessive stimulation of cholinergic receptors in the central and peripheric nervous system, that may even end by death of the subject), OP compounds also damage other tissues. Among them, OP inhibit DNA synthesis in the seminiferous epithelium (Rodríguez \& Bustos-Obregón, 2000), and are cytotoxic for spermatogenic cells in mice. Atef et al. (1995) have demonstrated that OP elicit morphophysiological damage of sperm, with cytogenetic damage of male germ cells (Bustos-Obregón \& Díaz, 1999).

Along this line of research, we have published a biotest model in mice to analyze testicular toxicants damage elicited by contamination with OP agropesticides. One single dose of parathion inhibited cauda epididymal spermatozoa counts, implying damage of the proliferating spermatogenic cells in observations done after 33,2 days (complete spermatogenic time in the mouse, Oakberg (1956)) of OP administration (Bustos-Obregón \& Gonzalez-Hormazabal, 2003; Sobarzo \& Bustos-Obregón, 2000).

Necrospermia and teratozoospermia (mostly of the tail) increased, with the presence of apoptotic cells and vacuolization of the seminiferous epithelium affecting mostly primary spermatocytes. This situation did not recover completely even after 50 days post exposure (Bustos-Obregón \& Diaz).

There is also chromatin damage, with aneuploid spermatozoa. They show metachromatic nuclei when examined in epifluorecence after acridine-orange staining (Bustos-Obregón \& Gonzalez-Hormazabal).

Paroxon is equally toxic and the commercial preparations of parathion and malathion are also very toxic.

In our animal studies, both in rodents and also in Eisenia foetida, cell and genetic damage is due to the overproduction of reactive oxygen species (ROS). (BustosObregón \& Iziga Goicochea, 2002). Therefore, the protective role of a potent ROS scavenger such a Melatonin, was analyzed (Sarabia et al., In press, 2009a).

This study evaluates the effect of a single dose of diazinon and melatonin - a powerful antioxidant-on plasmatic acetylcholinesterase activity and testis histopathology in adult mice 1 and 32 days post-treatment. Diazinon diminished the plasma acetylcholinesterase activity on day 1 post-treatment, although testosterone levels remained unaffected. Melatonin pretreatment prevented every alteration induced by diazinon, except a reduction of acetylcholinesterase plasmatic activity. Morphometrical analysis showed a decrease in seminiferous epithelium height. At day 1 , it is $34 \pm 5 \mu \mathrm{m}$ versus $47 \pm 4 \mu \mathrm{m}$ in the control. At day 32 these values are $32 \pm 8 \mu \mathrm{m}$ versus $50 \pm 4 \mu \mathrm{m}$ respectively. An increase in testicular superoxide dismutase (SOD) activity was detected (day 32). Testicular damage might be due to elevated concentrations of free oxygen radicals released upon diazinon exposure, inducing alterations in the DNA and promoting local apoptosis. However, antioxidant pretreatment with melatonin prevents or diminishes this damage. In addition, diazinon damages mouse sperm DNA, which is also prevented by melatonin.

On day 1, sperm from diazinon-treated mice showed increased DNA breakages and reduced chromatin packaging, whilst DNA damage increased only in the diazinon 2/3 LD50 group. Micronucleus test of bone marrow cells at day 1 , demonstrated somatic cell chromosomal damage in both diazinon-treated groups ( $28 \pm 1 \%$ with diazinon $2 / 3$ LD50 and $14 \% \pm 1 \%$ with diazinon $1 / 3$ LD50). Pretreatment with melatonin before diazinon acute administration improved all parameters studied on day 1 post injection of diazinon. The organophosphorous pesticide diazinon is a dose-dependent testicular toxicant that alters the sperm DNA structure; melatonin is able to prevent this damage (Sarabia et al., in press, 2009a).

Previous studies in our laboratory had shown similar results in mice intoxicated with the OP Malathion (M) which interferes with the normal spermatogenic cycle in mice, after a single dose and at intervals from 4 to 26 days. Increased teratozoospermia, acrosomal and flagellar damage were reported (Contreras \& Bustos-Obregón, 1999).

Damage is also noticed in immature mice exposed to Parathion (Sobarzo \& Bustos-Obregón), with reduced tubular diameter at days 7, 14 and 21, and a decreased epithelial height (noticed in adults after $\mathrm{M}$ treatment only at early intervals, i.e. at day 1 and 7), and a clear recuperation effect in M+Maca (aqueous extract of roots of Lepidium meyenii) , in agreement with reports by Gonzales et al. (2001 and 2003) in rats. It seems that the sensitiveness of the seminiferous epithelium changes with the age of the animals and that the post-meiotic germ cells are more sensitive to the OP. Maca helped the recovery of mitotic activity in mice treated with M (Bustos-Obregón \& Gonzalez-Hormazabal; Bustos-Obregón et al., 2005a), in keeping with our present histological observations that in the M+Maca group, atrophy and vacuolization of the epithelium decreases in this group compared to $\mathrm{M}$. 


\section{SOME OTHER ENVIRONMENTAL CHEMICAL CONTAMINANTS}

Lead intoxication model as an example of heavy metal toxicity. Many heavy metals are classical testicular toxicants, though the mechanism of their action may differ. Most of them represent environmental or labor risk. Lead toxicity is known to humanity since ancient times and mentioned in documents left by the Greeks, Romans and Arabs, and even the Egyptians. (Ahmad et al., 2003)

Lead is amply distributed in the environment and alters the physiology of many organic systems, including the male reproductive apparatus. A mouse experimental design was used to determine the effect of lead poisoning on testis and epididymal sperm characteristics, comparing blood plasma levels of lead and the alterations of reproductive parameters. In the literature, it has been reported that lead intoxication may cause oxidative stress (Schafer et al., 2005; Tchernitchin, 2002). Therefore, at the same time the protective effect of a very efficient reactive oxygen species (ROS) scavenger molecule, such as melatonin (MTN), was evaluated. Moreover, melatonin stimulates the activity of enzymes that metabolize ROS (El-Sokkary et al., 2003). Four groups of 16 animals were used. Group 1 (control), intraperitoneally injected with physiological solution, Group 2 injected with lead acetate $(6 \mathrm{mg} / \mathrm{kg}$ body weight), Group 3 injected with lead plus melatonin (daily injected $5 \mathrm{mg} / \mathrm{kg}$ body weight and lead $30 \mathrm{~min}$. thereafter) and Group 4 injected with melatonin only. Animals were sacrificed at 8, 16, 24 and 32 days after injections. Histometric parameters determined in testicular sections and epididymal cauda sperm were analyzed (Bustos-Obregón, 2005a). Lead intoxication resulted in lower animal weight and MTN elicited higher weight. The same was observed for testicular and cauda epididymal weight. Sperm counts are lower in $\mathrm{Pb}$ and preserved in MTN animals. Plasma levels of $\mathrm{Pb}$ were found elevated in all treated animals. Seminiferous tubular diameter was decreased for $\mathrm{Pb}$ animals, as well as seminiferous epithelium height and luminal diameter. Decreased percentage of testicular area occupied by tubules implies an expansion of the interstitial space in $\mathrm{Pb}$ treated animals. Lead provokes disorganization of seminiferous epithelium, which is prevented by MTN. In general, the lessions provoked by lead in the testis do not recuperate completely, since lead is not easily removed from the body.

One of the mechanisms involved in lead toxicity is the loss of tissue homeostasis by an imbalance between proand antioxidative factors, which elicits oxidative damage of proteins, lipids and DNA (El-Missiry, 2000).

Melatonin has the ability to neutralize ROS and inhibit lipid peroxidation induced by a variety of agents (Kim et al., 1998). Due to its low molecular weight and being lipophilic, melatonin is not only a good extracellular but also an excellent intracellular ROS scavenger (Reiter et al., 1995).

In lead intoxicated animals, probably due to these properties, Melatonin was able to preserve normal body, testicular and cauda epididymal weight. The protective effect of melatonin has been documented also against other toxic substances that elicit increased oxidative potential, such as ammonia (Lena \& Subramanian, 2003), cyanate (Melchiori et al., 1995), and agropesticides (Bustos-Obregón et al., 2005b; Sarabia et al., 2009 in press). In addition, melatonin enhances metabolism, as observed in all parameters determined in mice, even compared to controls, a situation that agrees with a report by Reiter (2000).

The decrease in sperm numbers observed in $\mathrm{Pb}$ treated animals may be due to damage of spermatogonia and spermatocytes as reported by Corpas et al (1995) and reported also by our group in E. foetida (Bustos-Obregón et al., 2005b; Sarabia et al., 2009a in press).

Plasmatic $\mathrm{Pb}$ values are high in $\mathrm{Pb}$ treated mice and MTN does not lower these values, but prevents or diminishes the toxic damage, as found in our work, since it controls ROS but does not interfere with absorption or distribution of lead in the body. El-Missiry, observed that MTN did not affect hepatic or plasmatic levels of $\mathrm{Pb}$, as found also by Patra et al. (2001), using alfa-tocopherol and ascorbic acid as antioxidant agents.

Histological observation of testicular sections of $\mathrm{Pb}$ treated mice reveals germ cell disorganization, epithelial vacuolization and cell loss (Fig. 1), as described by other authors (Batra et al., 1998). According to Adhikari et al. (2001), high doses of Pb elicit apoptosis of germ cells (Fig. 2 ), which is a common mechanism of action of many toxics, including lead and phosphorated pesticides.

Depending on the dose, $\mathrm{Pb}$ can enter the tight junctions that form the inter-Sertoli (so called blood-testis) barrier, damaging the epithelium, with a decrease in its height due to germ cell loss, thus increasing the tubular lumen. All these events are caused by an excess of ROS, elicited by $\mathrm{Pb}$ toxicity. It is also possible that $\mathrm{Pb}$ flows in a retrograde manner via the tubular lumen, after entering the rete testis. In conclusion, lead can cause many morphofunctional anomalies in different organs and tissues. In the case of the male reproductive organs, it might presumably cross the blood-testis barrier and damage germ and Sertoli cells, thus altering normal spermatogenesis and sperm production. This situation should be studied in depth. Melatonin is able to counteract these effects due to its 


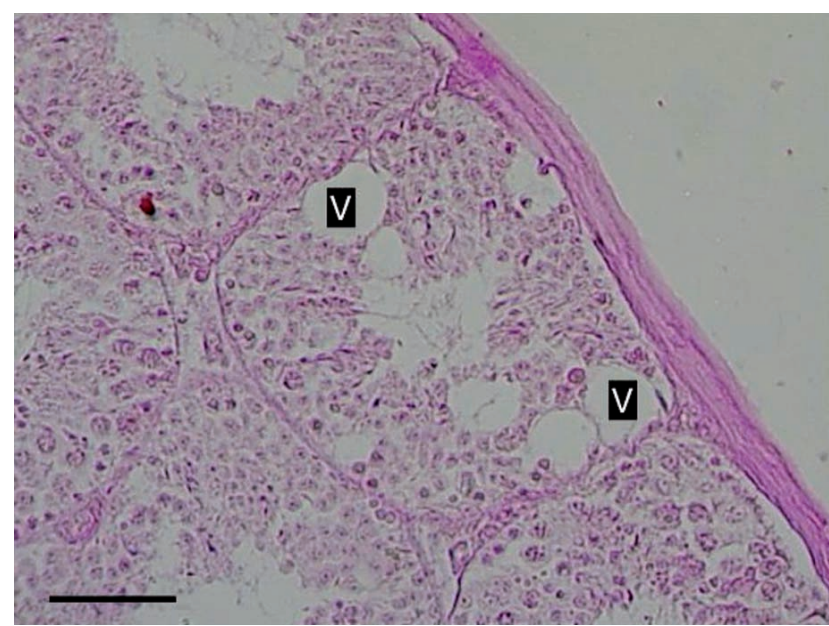

Fig. 1. Seminiferous tubule of lead treated mice. Vacuolization of the epithelium at different levels (V) (bar: $50 \mu \mathrm{m})$.

antioxidative role. Therefore, it may be possible to use it as a prophylactic agent to avoid lead cytotoxity in individuals exposed to lead in their daily work.

Boron as spermatogenic interfering chemical. Boron is a chemical element used in a variety of industrial activities. The frequent exposure to high doses of this element, or its related compounds, affects many organs in mammals, including reproductive alterations in male animals. In some places of the world, boron is a public health problem by contaminating drinking water, being the systems to reduce its concentration very costly. This is the case of the northern city of Arica, in Chile. The city is located in the desert, and the only available water supply comes from sources contaminated with boron since they originate from a volcanic area, rich in borates and other boron-containing compounds.

WHO recommendation (1998) is of $0.5 \mathrm{mg} / \mathrm{L}$ of drinking water, whereas in the city of Arica the water supply has between 6 and $12 \mathrm{mg} / \mathrm{L}$ of boron. Adult ( 85 days old) $\mathrm{CF}-1$ male mice were exposed to $12 \mathrm{mg} / \mathrm{L}$ of boron in the drinking water for 42 days, and the controls drank tap water of the city of Santiago ( $0.13 \mathrm{mg} / \mathrm{L}$ of boron). Boron elicits histological changes in the intoxicated animals, characterized by epithelial vacuolization, blocking of the tubular lumen and tubular atrophy. The tubular diameter in the boron animals is larger than the control group (233.3 $\mu \mathrm{m}$ vs 208.9 $\mu \mathrm{m})$. Height of the seminiferous epithelium are also greater for the boron group ( $58.3 \mu \mathrm{m}$ vs $50.4 \mu \mathrm{m}$ for the control). The same is seen for the tubular lumen (the boron group is $12.1 \mu \mathrm{m}$ larger than the control group, that shows $60.5 \mu \mathrm{m}$ in diameter). It is known that boron follows the same metabolic pathways in animals and humans, but in men there is no clear demonstration of boron toxicity affecting male reproductive potential. In laboratory animals, boron compromises body development and reproductive function.

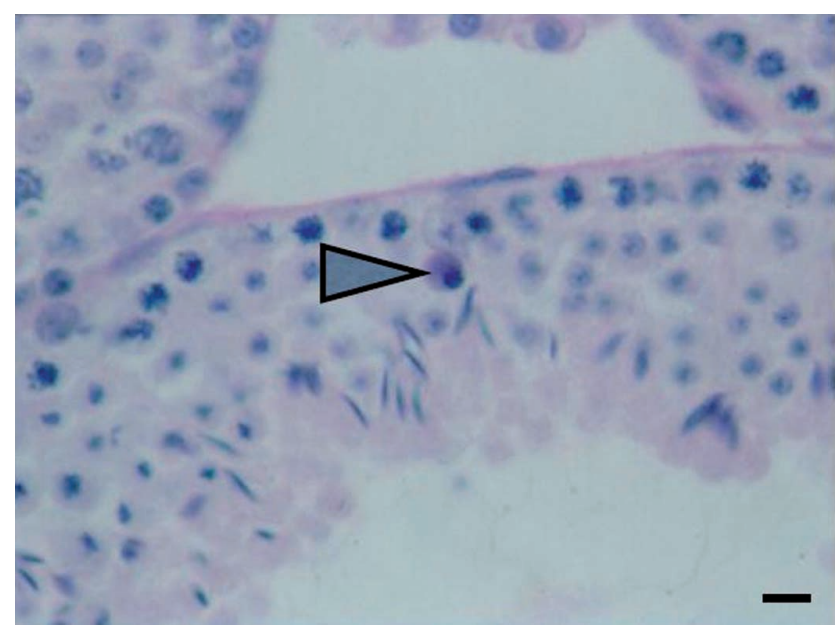

Fig. 2 Seminiferous tubule of lead treated mice. Apoptotic nucleus of spermatocyte (arrow) (bar: $10 \mu \mathrm{m})$.

The LOAEL value showing diminished body weight for rat fetuses is $13 \mathrm{mg}$ of boron/day/ $\mathrm{kg}$. of body weight. If doses go up to $25 \mathrm{mg} / \mathrm{day} / \mathrm{kg}$, testicular pathology is evident $(\mathrm{Ku}$ et al., 1993). The morphometric findings in mice probably represent adaptation of the seminiferous tubules, which undergo hypertrophy to compensate the diminished spermatogenic activity caused by boron, and reflected in a lower sperm count compared to controls. It would be interesting to establish in future works if the effect of boron in rodents follows stage-specific pattern in order to better understand the pathophysiology of the process.

In addition, boron's effect on mice liver exposed for 8, 42 or 49 days was evaluated (Bustos-Obregón et al., 2008), considering the role of liver in metabolizing androgenic steroids. Boron alters the production of collagen by the cells of Ito, fibroblast and endothelial cells thus it elicits liver functional and architectural damage that may have endocrine consequences for normal testicular function.

\section{BIOSENTINEL SPECIES}

A number of different terrestrial and aquatic species, both invertebrates and vertebrates, have been used for testing environmental contamination. Among them Eisenia foetida, the Californian red earthworm, has been used to analyze the spermatogenic damage due to pesticide soil contamination (Bustos-Obregon \& Iziga-Goicochea), and as an example of monitoring spermatogenic damage elicited by the OP Diazinon, and the protective role of Melatonin (BustosObregon et al., 2005b). Diazinon is a synthetic pesticide widely used in agriculture, floriculture, and veterinary medicine. Eisenia foetida (Annelida, Oligochaeta) is an excellent biosentinel to evaluate toxic risk of xenobiotics in terrestrial ecosystems. 
For this purpose, Eisenia foetida were reared in laboratory conditions. One group was exposed to increasing doses of the OP diazinon and examined at 1, 7, 10, 15 and 30 days thereafter. Gonadal morphology was examined (testicular and seminal vesicles; E. foetida is an hermaphrodite organism), as well as the quality of chromatin of sperm from the seminal vesicles. To half of the treated animals, melatonin was added as a ROS protective agent.

Diazinon provokes decrease in sperm count that is dose dependent, and melatonin cancels almost completely this effect, as well as prevents chromatin damage as demonstrated by the commet assay (Bustos-Obregón \& Iziga-Goicochea).

The survival of the worms is also preserved by melatonin so that after 30 days of rearing diazinon kills $60 \%$ of the animals when given at the dose of 3/4 LD50, whereas only $20 \%$ dies when melatonin is added to the cultures.

It may be concluded that Eisenia foetida is an animal model, easy to use, inexpensive and representative of the changes that OP may elicit in other organisms. It is also confirmed that this earthworm is an excellent biosentinel species.

Among bioindicators, many other organisms have been tested in terms of their response to chemical pollution affecting embryonic development, from sea invertebrates, such as Octopus mimus (Gutiérrez-Pajares et al., 2003), to fish, such as zebra fish (Lara et al., 2002), and many other amphibian, terrestrial or aquatic animals (Bustos-Obregón \& Vargas, 2005; Vargas \& Bustos Obregón).

BUSTOS-OBREGÓN, E. \& HARTLEY, B. R. Ecotoxicología y daño testicular. (Contaminación química ambiental). Revisión. Int. J. Morphol., 26(4):833-840, 2008.

RESUMEN: Esta revisión considera el daño testicular provocado por la contaminación química ambiental. Incluye un breve comentario sobre toxicología ambiental a modo de introducción respecto a la polución química ambiental y destaca la importancia de este campo de estudio actual y su impacto sobre la salud reproductiva masculina. Además se presenta un modelo experimental animal concerniente al efecto de agropesticidas organofosforados como tóxicos testiculares. Se consideran dos contaminantes químicos relevantes y su efecto en el testículo como son el clásico caso del plomo y el menos conocido caso del boro y sus efectos sobre la espermatogénesis. También se trata el tema de las especies biocentinelas y su importancia para el monitoreo de la evolución de ecosistemas acuáticos y/o terrestres. En conclusión, es necesario insistir que la salud medioambiental está íntimamente relacionada con la salud reproductiva de todos los seres vivos.

PALABRAS CLAVE: Contaminación química ambiental-daño testicular.

\section{REFERENCES}

Adhikari, N.; Sinha, N.; Narayan, R. \& Saxena, D. K. Lead induced death cell in testis of young rats. J. of Applied Toxicology, 21:275-7, 2001.

Ahmad, I.; Sabir, M. \& Yasin, K. F. Study of the effects of lead poisoning on the testes in albino rats. Pak. J. Med. Res., 42:97-101, 2003.

Atef, M.; Youssef, S.; Ramadan, A.; Nawito, M.; El-Sayed, M. \& Abdel-Rahman, H. Influence of Phoxim on testicular and seminal vesicle organs, testosterone and cholinesterase level and its tissue residues in male rats. Dtsch. Tierarztl. Wochenschr., 702:1-5, 1995.

Batra, N.; Nehru, B. \& Bansal, M. P. The effect of zinc supplementation on the effects of lead on the rat testis. Reproductive Toxicology, 12:535-540, 1998.

Bustos-Obregón, E. \& Díaz, O. Ultraestructure of mouse teratozoospermia induced by Parathion. Asian J. Androl., 1:79-80, 1999.

Bustos-Obregón, E. Adverse Effects of Exposure to Agropesticides on Male Reproduction. APMIS Denmark, 109:233-242, 2001.

Bustos-Obregón, E. \& Iziga-Goicochea, R. Pesticide soil contamination mainly affects earthworm male reproductive parameters. Asian J. Androl., 195-19, 2002.

Bustos-Obregón, E. \& Gonzalez-Hormazabal, P. Mice testicular damage elicited by Malathion. Int. J. Morphol., 21:155-9, 2003.

Bustos-Obregón, E. \& Vargas, A. Bioensayo de toxicidad crónica utilizando poblaciones de crustáceo braquípodo artemia salina en distintas etapas de su desarrollo temprano expuestas al organofosforado Diazinon. Abstract. 
$6^{\circ}$ Congreso Iberoamericano y $3^{\circ}$ Congreso Latinoamericano de Contaminación y Toxicología Ambiental. CICTA2005. Cadiz, España. 25-28, Septiembre, 2005.

Bustos-Obregón, E.; Yucra, S. \& Gonzales, G. Lepidium meyenii (Maca) reduces spermatogenic damage induced by a single dose of malathion in mice. Asian J. Androl., 7:71-6, 2005a.

Bustos-Obregón, E.; González, J. R. \& Espinoza, O. Melatonin as protective agent for the cytotoxic effects of Diazinon in the spermatogenesis in the earthworm Eisenia foetida. It. J. Anat. Embryol., 110:159-65, 2005b.

Bustos-Obregón, E. Testicular Toxicants. Reviews on Basic. Andrology, 4:61-72, 2007.

Bustos-Obregón, E.; Hartley, R. \& Catriao-Galvez, R. Histopathological effects of boron on mouse liver. Int. J. Morphol. 26(1):155-64, 2008

Brinkworth, M. H. \& Handelsman, D. J. Occupational and environmental Influences on Male Infertility. In: Nieschlag E., Behre HM, editors Andrology: Male Reproductive Health and Dysfunction. Springer 13:241-253, 1997.

Chapalamadugu, S. \& Chaudhry, G. Microbiological and biotechnological aspects of metabolism of carbamates and organophosphate. Critical Reviews in Biotechnology, 12:357-89, 1992.

Contreras, H. \& Bustos-Obregón, E. Morphological alterations in mouse testis by a single dose of Malathion. J. Exp. Zool., 248:355-39, 1999.

Corpas, I.; Gaspar, I.; Martinez, S.; Codesa, J.; Candelas, S. \& Antonio, M. T. Testicular alterations in rats due to gestational and early lactational administration of lead. Reproductive Toxicology, 14:57-62, 1995.

De Azevedo, F. A. \& Da Matta Chasin, A. A. As Bases Toxicológicas de Ecotoxicologia. Ed. Vida e Consciência, São Paulo, 2003.

El-Missiry, M. Prophylactic effect of melatonin on leadinduced inhibition of heme biosynthesis and deterioration of antioxidant systems in male rats. J. Biochemical Molecular Toxicology, 14:57-62, 2000.

El-Sokkary, G. H.; Kamel, E. S. \& Reiter, R. J. Prophylactic effect of melatonin in reducing lead-induced neurotoxicity in the rat. Cellular and Molecular Biology Letters, 8:46170, 2003.
Ferrer, A. \& Martínez, J. Toxicologia Clínica. En Insecticidas. Marruecos. Nogué y Nolla. Ed. Springer-Verlag Ibérica 233-252, 1993

Gomero, L. \& Von Hildebrand, A. Los plaguicidas, remedios que matan. Consumo de plaguicidas en el Perú y sus consecuencias ambientales. Instituto de Desarrollo y Medio Ambiente (IDMA) Ediciones J. R. Lima, 1990.

Gonzales, G. F.; Gaseo, M.; Cordova, A.; Chungkin, A.; Rubio, J. \& Villegas, L. Effect of Lepidium meyenii (Maca) roots on spermatogenesis of male rats. Asian J. Androl., 3:231-3, 2001.

Gonzales, G. F.; Rubio, J.; Chung, A.; Gaseo, M. \& Villegas, L. Effect of alcoholic extract oí Lepidium meyenii (Maca) on testicular function in male rats. Asian J. Androl., 5:349$52,2003$.

Gutiérrez-Pajares, J.; Olivares, A. \& Bustos-Obregón, E. Mollusca: Cephalopoda embryo misdevelopment due to chronic exposure to the organophosphorus pesticide parathon. Int. J. Morphol., 21:251-5, 2003.

Hsu, H.; Cook-Deegan, R. \& Shukril, A. The use of chemical weapons: conducting an investigation using survey epidemiology. Am. J. Anal., 262:640-3, 1989.

Johnson, A. D.; Gomes, W. R. \& Vandemark, N. L. (Eds). The Testis. New York, Academic Press. 10; V. III. 378481 and 11:483-554, 1970.

Kim, S. J.; Reiter, R. J.; Rouvier, M. V.; Qi, W.; El-Sokkary, G. H. \& Tan, D. X. 2-Nitropropane-induced lipid peroxidation: antitoxic effects of melatonin. Toxicology, 130:183-90, 1998.

Ku, W.; Chapin, R.; Wine, R. \& Gladen, B. Testicular toxicity of boric acid (BA): Relationship of dose to lesion development and recovery in the F344 rat. Reprod. Toxicol., 4:305-19, 1993.

Lara, A.; Leóz, E. \& Bustos-Obregón, E. Efecto del Parathion sobre el desarrollo embrionario del pez Danio rerio. I Reunión Anual de la Soc. Androl. y Gametol. de Chile, 2002.

Lena, P. \& Subramanian, P. Evaluation of the antiperoxidative effects of melatonin in ammonium acetate-treated Wistar rats. Polish J. of Pharmacology, 55:1031-6, 2003.

Martinez J. Intoxicación por órgano fosforados: enfoque actual de esta entidad. Clínica Médica, 98:702-705, 1992. 
Melchiori, D.; Reiter, R.; Attia, A.; Hara, M.; Burgos, A. \& Nistico, G. Potent protective effect of melatonin on in vivo paraquat-induced oxidative damage in rats. Life Sciences, 56:83-9, 1995.

Ming-Ho, Yu. Enviromental Toxicology. $2^{\text {nd }}$ ed. Biological and health effects of pollutants. CRC Press. Boca Raton, Fla. USA 1:1-4, 2005.

Nieschlag, E. \& Belise, H. M. (Eds). Male reproductive health and disfunction. Springer-Verlog, Berlin. 13, 1997.

Oakberg, E. F. Duration of spermatogenesis in the mouse and timing of stages of the cycle of the seminiferous epithelium. Am. J. Anat., 99:507-16, 1956.

Ortiz, C. Alteraciones Seminales encontradas en ex-trabajadores bananeros del occidente Nicaragüense producto de la exposición laboral al 1,2 dibromo-3cloropropano (DBCP), durante la década de 1970. MSc-Thesis, Faculty of Medicine, University of Leon, Nicaragua, 2006.

Ortiz-Hernández, M.; Sánchez-Salinas, E.; Vázquez-Duhalt, R. \& Quintero-Ramírez, R. Plaguicidas Organofosforados y Ambiente. Biotecnología, 3:129$151,1997$.

Patra, R. C.; Swarup, D. \& Dwivedi, S. K. Antioxidant effects of a-tocopherol, ascorbic acid and L-methionine on lead induced oxidative stress to the liver, kidney and brain in rats. Toxicology, 162:81-88, 2001.

Pomerol, J. M. \& Arrondo, J. L. Práctica Andrológica. Barcelona, Masson-Salvat, 1994.

Reiter, R. J.; Melchiorri, D.; Sewerynek, E.; Poeggeler, B.; Barlow-Walden, L. \& Chuang, J. I. A review of the evidence supporting melatonin's role as an antioxidant. J. Pineal Res., 18:1-11, 1995.

Reiter, R. J. Melatonin: Lowering the high price of free radicals. News Physiol. Sci., 15:246-50, 2000.

Rodríguez, H. \& Bustos-Obregón, E. An in vitro model to evaluate the effect of an organophosphoric agropesticide on cell proliferation in mouse seminiferous tubules. Andrology, 32:1-5, 2000.

Sarabia, L.; Maurer, I. \& Bustos-Obregón, E. Melatonin prevents damage elicited by the organophosphorous pesticide diazinon on mouse sperm DNA. Ecotoxicology and Environmental Safety, 72:663-66, 2009.
Sarabia, L.; Maurer, I. \& Bustos-Obregón, E. Melatonin prevents damage elicited by the organophosphorous pesticide diazinon on the mouse testis. Ecotoxicology and Environmental Safety, In Press, 2009.

Schafer, J. H.; Glass, T. A.; Bressler, J.; Todd, A. C. \& Schwartz, B. S. Blood lead is a predictor of homocysteine levels in a population-based study of older adults. Environ. Health Perspect., 113:31-5, 2005.

Sobarzo, C. \& Bustos-Obregón, E. Acute effect of parathion on the seminiferous epithelium of immature mice. Rev. Chil. Anat., 18(1):61-8, 2000.

Tchernitchin A. Efectos sobre la Salud de los Contaminantes Ambientales y Propuestas de Solución. Vida Médica 54:74-8, 2002.

Vargas, C. A. \& Bustos-Obregón, E. Método de estudio utilizando microcrustáceos acuícolas como bioindicadores de ambientesacuáticos expuestos a contaminación química. XIII Reunión Científica Anual Sociedad de Biología de Cuyo. III Reunión Anual Sociedad Argentina de Microscopía. Uspallata-Mendoza. 15-17 December, 2005.

World Health Organization. Guidelines for drinking water quality. $2^{\text {nd }}$ ed. Addendum to. Health criteria and other supporting information, Gèneve, Suisse, 1998. V. 2.

Correspondence to:

Eduardo Bustos-Obregón

Laboratory of Biology of Reproduction

University of Chile Medical School,

POBox 70061-Santiago 7

CHILE

Email: ebustos@med.uchile.cl

Received: 17-09-2008

Accepted: 22-10-2008 